\title{
International study on Artemia LXIII. Field study of the Artemia urmiana (Günther, 1890) population in Lake Urmiah, Iran
}

\author{
Gilbert Van Stappen ${ }^{1}$, Gholamreza Fayazi ${ }^{2}$ \& Patrick Sorgeloos ${ }^{1}$ \\ 'Laboratory of Aquaculture \& Artemia Reference Center, University of Ghent, Rozier 44, B-9000 Ghent, Belgium \\ ${ }^{2}$ Iran Fisheries Company (Shilat), Aquaculture Department, Mahan Alley, Vesal Shiraz Ave., 14168 Tehran, Iran
}

Key words: Artemia, population assessment, Lake Urmiah, Iran

\begin{abstract}
Lake Urmiah is a large (total surface $4750-6100 \mathrm{~km}^{2}$ in recent times) thalassohaline hypersaline lake (150-180 g $\mathrm{I}^{-1}$ in the period 1994-1996), located in northwestern Iran. It is the habitat of the endemic Artemia urmiana. Over the period July 1994-January 1996 a sampling campaign was organized: 36 fixed sampling stations, distributed over the entire lake's area, were sampled weekly to determine water temperature, salinity and transparency. At each occasion a filter net was dragged over a distance of $400 \mathrm{~m}$ in the superficial water layer to assess the density and composition of the Artemia population. A more limited sampling campaign focused on the annual fluctuations in chlorophyll concentration and on the reproductive behaviour of the brine shrimp population. Several stages of brine shrimp survived during winter months (water temperature $3 \mathrm{C}$ ) at low densities. Compared to available data for the Great Sall Lake, USA, Lake Urmiah shows a low algal biomass and overall low Artemia density. The increasing grazing pressure of the developing brine shrimp population in spring seems to prevent the phytoplankton from reaching high blooming concentrations, and oviparity is the dominant reproductive mode throughout the reproductive season.
\end{abstract}

\section{Introduction}

In 1994 a cooperative project was launched between the Iran Fisheries Company (Shilat), a governmental agency responsible for the exploitation of Artemia urmiana Günther (1890) from Lake Urmiah, and the Laboratory of Aquaculture \& Artemia Reference Center of the University of Ghent, Belgium. The aim of this project was the study of the Artemia resources in the lake, and the application of this Artemia strain in aquaculture. Ecological data on Lake Urmiah are scarce, especially in the international scientific literature. An intensive study was therefore required to determine the sustainable level of exploitation for the lake's natural resources.

A sampling campaign was organized, covering the entire lake surface and two consecutive production seasons. The objectives of this sampling campaign were to collect data on the seasonal evolution of the population composition, reproductive behaviour and biomass density of Artemia in Lake Urmiah; and to relate these data to information collected on abiotic variables and algal biomass.

\section{Site description}

Lake Urmiah is a thalassohaline lake (Azari Takami, 1993) located in northwestern Iran (Fig. 1) at an altitude of $1250 \mathrm{~m}$ above sea level. The total surface area fluctuates betw'een 4750 and $6100 \mathrm{~km}^{2}$ (I.öffler, 1961; Azari Takami, 1987). Since the construction of a causeway in 1989, the lake has been divided into northern and southern parts (Fig. 2). A 1400-m gap in this dam allows a limited exchange between both parts. A maximum length and width of 128-149 km and $50 \mathrm{~km}$ are reported, respectively (Löffler, 1961; Azari Takami, 1987). The average depth is close to $6 \mathrm{~m}$, maximal depth is $16 \mathrm{~m}$. Annual inputs to the lake are $6.9 \times 10^{9} \mathrm{~m}^{3} ; 21$ permanent and seasonal rivers (annual inflow $4.9 \times 10^{9} \mathrm{~m}^{3}$ ) flowing through agricultural, urban and/or industrial areas, drain into 


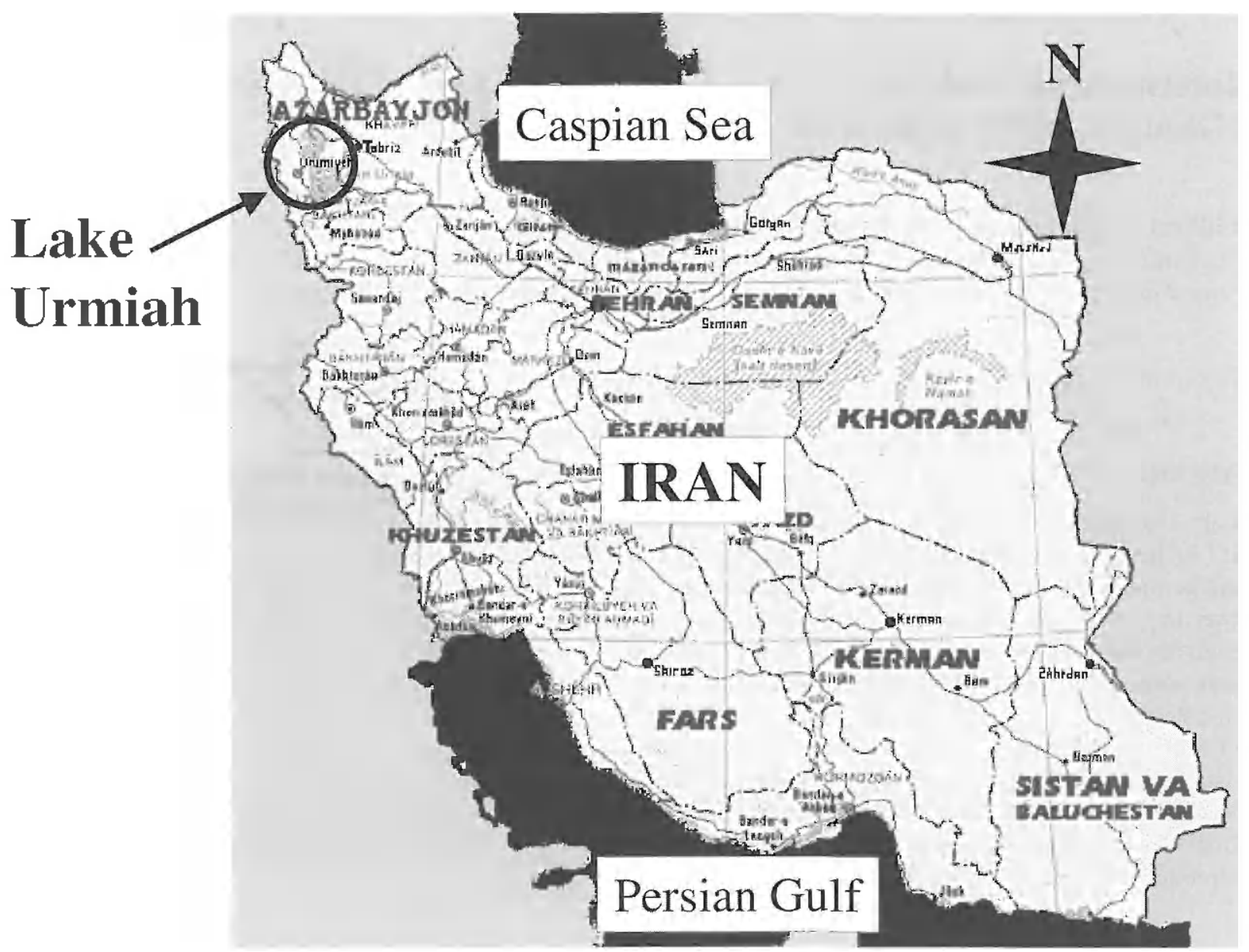

Figure 1. Map of Iran with location of J_ake Urmiah.

this terminal lake (predominantly into its south arm), largely without wastewater treatment (Ghaheri et al., 1999). The total water reserve is estimated between 12 $\times 10^{9} \mathrm{~m}^{3}$ (Azari Takami, 1993) and 25-27 × $10^{9} \mathrm{~m}^{3}$ (Ghaheri et al., 1999). The lake is located in a semiarid area with annual average precipitation in the range 200-300 $\mathrm{mm}$ (Ghaheri et al., 1999). In view of its importance for migrating birds, the lake has a status of natural reserve.

\section{Materials and methods}

A set of precisely located sites was sampled weekly in the period July 1994-January 1996. These sites were spread over the entire lake's surface, taking into account its topography, and balancing coastal versus off-shore areas, zones with or without reported occur- rence of cyst accumulations, and deep versus shallow: areas.

The south arm was subdivided into four sectors (A-D) along the lines of $37^{\circ} 30^{\prime} \mathrm{N}$ and $45^{\circ} 30^{\prime} \mathrm{F}$ (Fig. 2), and the north arm into two sectors (E, F) along $38^{\circ} \mathrm{N}$. In each of these six sectors four surface (see further; $t$-sites) and two subsurface ( $p$-sites) sampling sites were identified, and marked by buoys. Efforts were made to take a maximum of samples within the shortest possible time lapse (2-3 days). For surface sampling a $100-\mu \mathrm{m}$ mesh size net $(60 \times 20 \mathrm{~cm}$; length, $2.5 \mathrm{~m}$ ) was dragged just below: the water surface over a length of $400 \mathrm{~m}$ at an approximate speed of $5 \mathrm{~km} / \mathrm{h}$ (the trajectory was indicated by two buoys); for subsurface sampling the same net was dragged for $100 \mathrm{~m}$ at $0.5-1 \mathrm{~m}$ below the water surface.

The following abiotic variables were recorded on the spot for each sample: air and surface water temperature (using a thermometer with $0.1^{\circ} \mathrm{C}$ accuracy), 


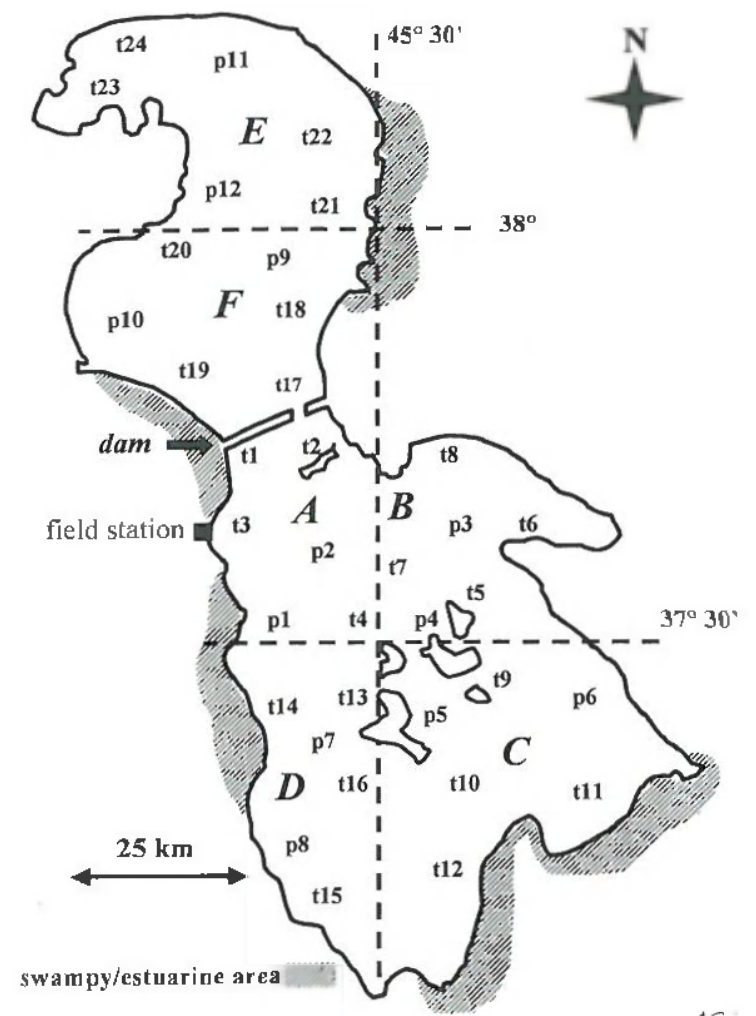

Figure 2. Lake Urmiah with overview of sampling sites $\left(\mathrm{t}_{1--24}\right.$, surface samples: $p_{1--12}$, samples at $0.5-1.0 \mathrm{~m}$ depth, A-E: sectors).

salinity (using a temperature compensated refractometer), transparency (measured by means of a Secchi disk with two black and two white quadrants), meteorological observations (wind, wave height, precipitation, etc.) and other observations (e.g., cyst or biomass accumulation, concentration of predating birds, etc.).

During the period November 1995-June 1996 monthly surface samples were taken with Rüttner bottles at each site for determination of the algal cell densities (Dunaliella, Nitzschia, Navicula, Cymbella, Cyclotella, Oscillatoria); samples were sieved over a $120-\mu \mathrm{m}$ mesh filter to remove zooplankton and transported in cooled, dark containers to the laboratory. Here they were filtered onto $0.45-\mu \mathrm{m}$ Whatman GF/F filters and frozen. The concentrations of chlorophyll $a, b$ and $c$ were determined spectrophotometrically according to Strickland \& Parsons (1972).

The Artemia hiomass collected at each site was stored in separate cooled plastic recipients and transferred to the laboratory for analysis. The wet weight of each sample was determined, and the population composition was analysed as follows: per sample $300-500$

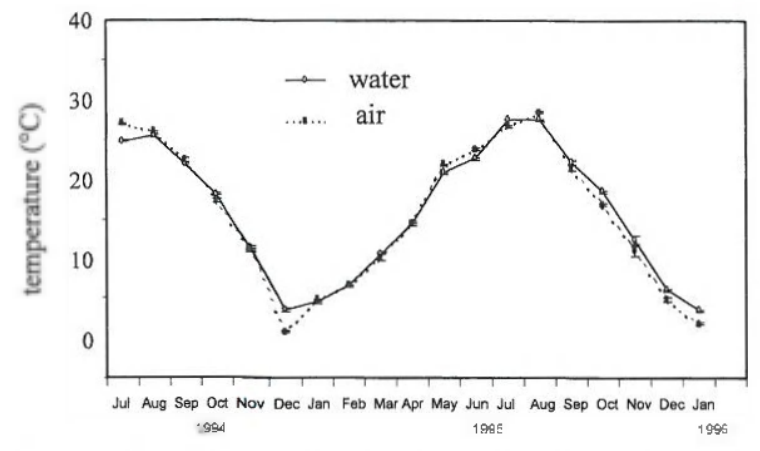

Figure 3. Seasonal fuctuations of air and uater temperatures (values, with standard error bars, arc averages of all sampling sites).

individuals. taken at random. were observed and sorted into cysts, nauplii/metanauplii or juveniles/adults (expressed as percent of total numbers). Adult females were classified as 'reproducing' or 'non-reproducing', depending on the presence of offspring in the brood pouch. Finally for each sample collected in the period May 1995-January 1996, the reproductive mode and brood size were analysed. Ten reproducing females (if present) out of each sample were dissected and the percentage of females reproducing ovoviviparously or oviparously, and average and maximal brood sizes were determined separately for the two modes of reproduction.

\section{Results}

\section{Abiotic conditions}

The surface water temperatures ranged between $3.1^{\circ} \mathrm{C}$ (average for December 1995) and $27.5^{\circ} \mathrm{C}$ (August 1995), and followed the fluctuations of the air temperature very closely (Fig. 3). In winter there were several days with moderate frost; the lowest water temperature recorded was $-1.3^{\circ} \mathrm{C}$.

The difference in salinity between both parts of the lake was limited $\left(5-10 \mathrm{~g}^{-1}\right.$ lower in south arm as a consequence of river inflow), and tended to become minimal in winter months (Fig. 4). Salinity peaked in November-December (177 $\mathrm{g} !^{-1}$ in the south arm) and was lowest in May-June $\left(151 \mathrm{~g} \mathrm{l}^{-1}\right)$. There were only limiled salinity differences between the sampling sites (maximally $\sim 20 \mathrm{~g} \mathrm{l}^{-1}$ ). In spite of the estuaries discharging into the lake, there were no vast areas of low or intermediate salinity.

Large seasonal (Fig. 5) and local (Fig. 6) variations in transparency were observed: in Iune 1995, at 


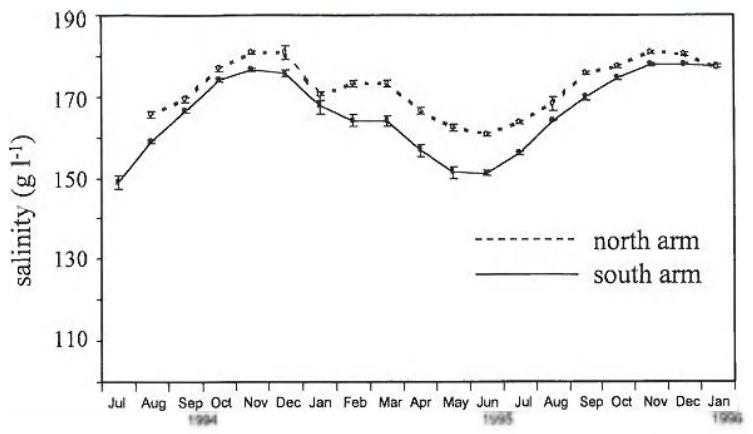

Fgure 4. Seasonal salinity fluctuations (values, with standard error bars, are averages of all sampling sites).

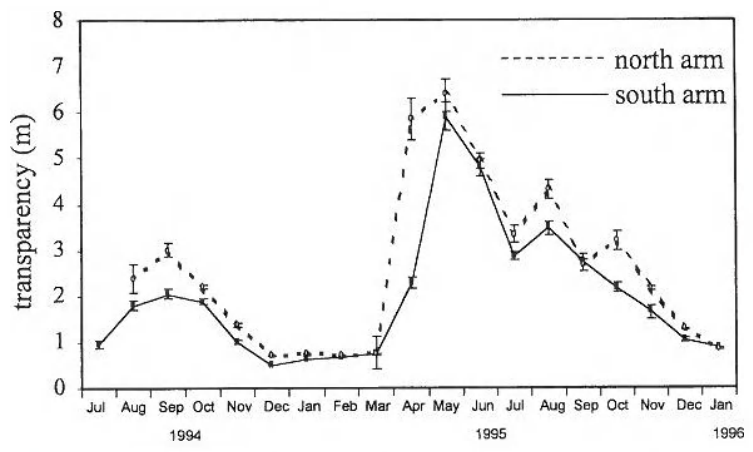

Figure 5. Seasonal fuctuations of uater transparency (ralues, with standard error hars, are averages of all sampling sites).

some sites a transparency of $10 \mathrm{~m}$ was observed, while in December 1994 values as low as $0.3 \mathrm{~m}$ occurred. Monthly averages were higher in the northern than in the southern arm. In summer 1995 much higher values were recorded than in summer 1994.

Precipitation occurred mainly in the winter season (November-mid-February), although there were some scattered showers in April-May 1995. Stormy weather was frequent in spring and aulumn, with a peak in November 1995. No empirical relation could be established between weather conditions, water transparency, and cyst or biomass accumulation.

\section{Algal biomass}

Chlorophyll values ranged between 0 and $4.71,4.33$ and $4.84 \mu \mathrm{g} \mathrm{I}^{-1}$ (chlorophyll $a, b, c_{1}+c_{2}$, respectively). Average monthly values, however, seldom exceeded $1 \mu \mathrm{g} \mathrm{l}^{-1}$. Chlorophyll levels reached a maximum in November-December (Fig. 7). The decline through spring and early summer resulted in minimal values at the end of the sampling period (June 1996). The phytoplankton thus reached a relative bloom when the Artemia population was nearly absent and de- creased, presumably due to increased brine shrimp grazing, from late winter onwards.

The local variations in chlorophyll concentration (Fig. 8) roughly reflect the local transparency fluctuations (Fig. 6), illustrating the potential use of water transparency measurements for assessing algal biomass. Coastal and estuarine areas were generally more productive than the central areas of the lake.

Cell concentrations of the green unicellular alga Dunaliella fluctuated between 400 cells ml-1 in August 1995 and 3000 cells ml m$^{-1}$ in February 1996. Values for other algae (Nitzschia, Navicula, Cymbella, Cyclotella, Oscillatoria) were below 100 cells $\mathrm{ml}^{-1}$ throughout the year.

\section{Artemia population}

The brine shrimp population in Lake Urmiah exhibits similar seasonal fluctuations (Fig. 9) to that reported for the Great Salt Lake (Gliwicz et al., 1995) but differs in a few particular characteristics. Cysts were found throughout the y'ear, with a minimum in late spring and summer, and a maximum in autumn and winter. Nauplii and metanauplii made up a very high fraction of the samples in summer 1994 (up to more than $70 \%$ ). This fraction fell sharply in autumn, remained at a minimum during winter, and reached a maximum again (though at a much lower level, $\sim 40 \%$ ) in March and April 1995, due to cyst hatching. The new peak in July/August may result from ovoviviparous reproduction in June/July or from further recruitment from cysts. The decline in autumn/winter 1995 was even more drastic than in 1994, and in January 1996 only very low numbers of (meta)nauplii were observed. Nevertheless throughout the winter months nauplii were still found in the superficial water layers, where the temperature dropped below $5^{\circ} \mathrm{C}$. Jureniles and adults made up less than $20 \%$ of the numbers of brine shrimp in summer 1994, increased in early autumn, and fell to a minimum in winter. In summer 1995, a peak for juveniles/adults was reached in JulyAugust; in January 1996 few jureniles/adults were found in the superficial water layers.

There were no obvious differences in population composition between the samples taken at the surface (t-samples) or at a depth of $0.5-1.0 \mathrm{~m}$ (p-samples), except for a slightly higher occurrence of (floating) cysts in the surface samples.

Occasional sampling in deeper water layers (1$3 \mathrm{~m}$ ) showed that numerous cysts remained in suspension in the water column, confirming laboratory 

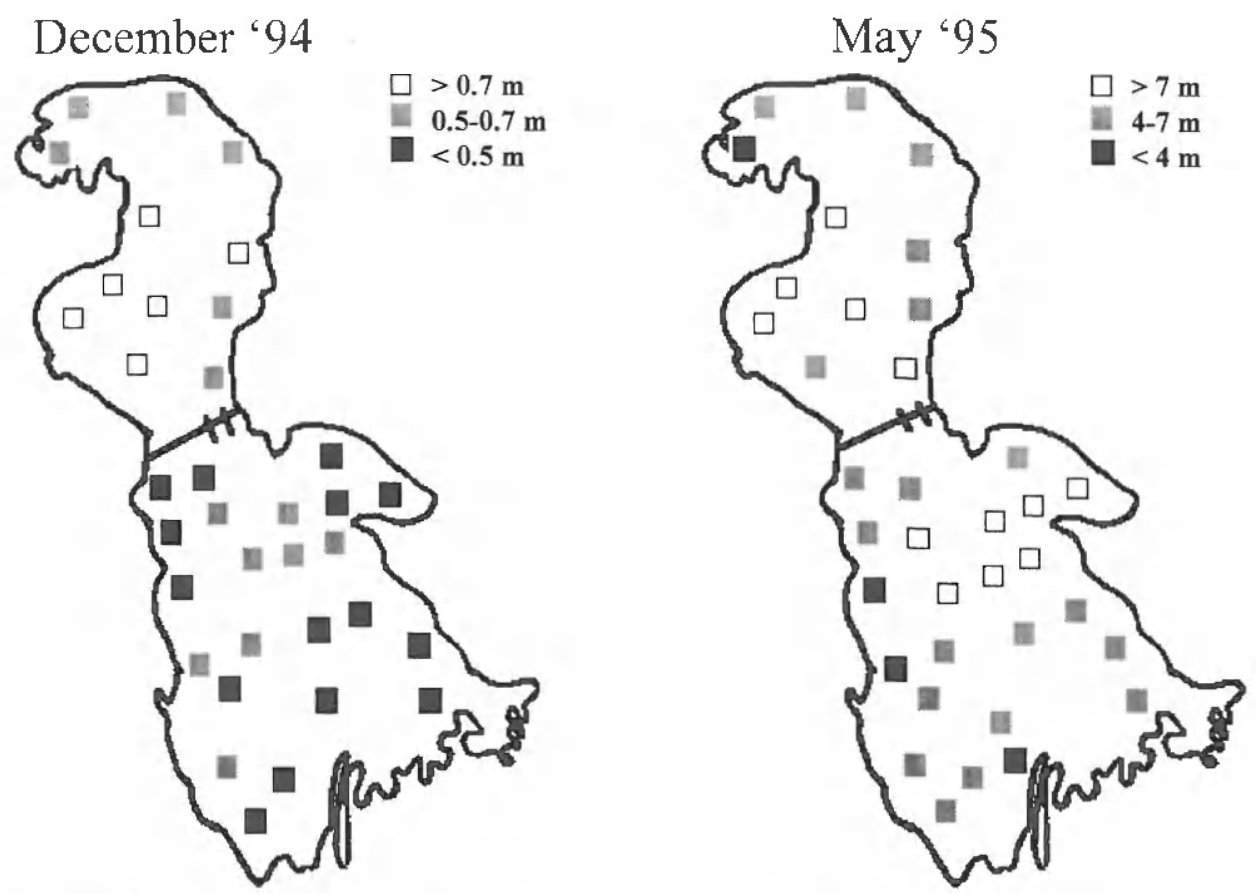

Figure 6. Local transparency variations in season of minimal (December 1994) and maximal (May 1995) water transparency.

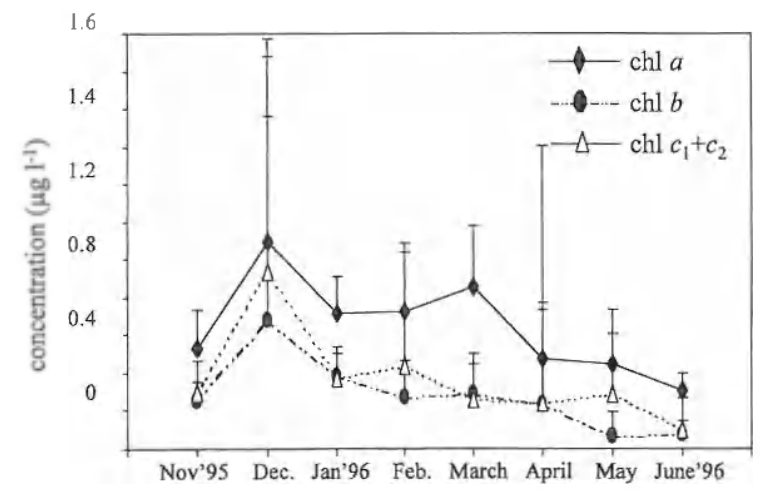

Figure 7. Seasonal fuctuations of chlorophyll $a_{1} b$ and $c_{1}+c_{2}$ concentration (ialues, with standard error bars, are averages of all sampling sites).

experiments (Pador, 1995) showing that below $150 \mathrm{~g}$ $1^{-1}$ up to $50 \%$ of the A. urmiana cysts remained in suspension. Ev'en at salinities as high as $200 \mathrm{~g}^{-1}$ no full buoyancy of all cysts was reached.

There was a high incidence of males $(2: 1)$ in the summer during 1994 and 1995, but the sex ratio declined in autumn, and reached $0.5-1: 1$ in December/January (Fig. 10).

The ratio of reproducing females/total females generally fluctuated in the range 50-60\% (Fig. 11), except for winter and carly spring, when reproduc-

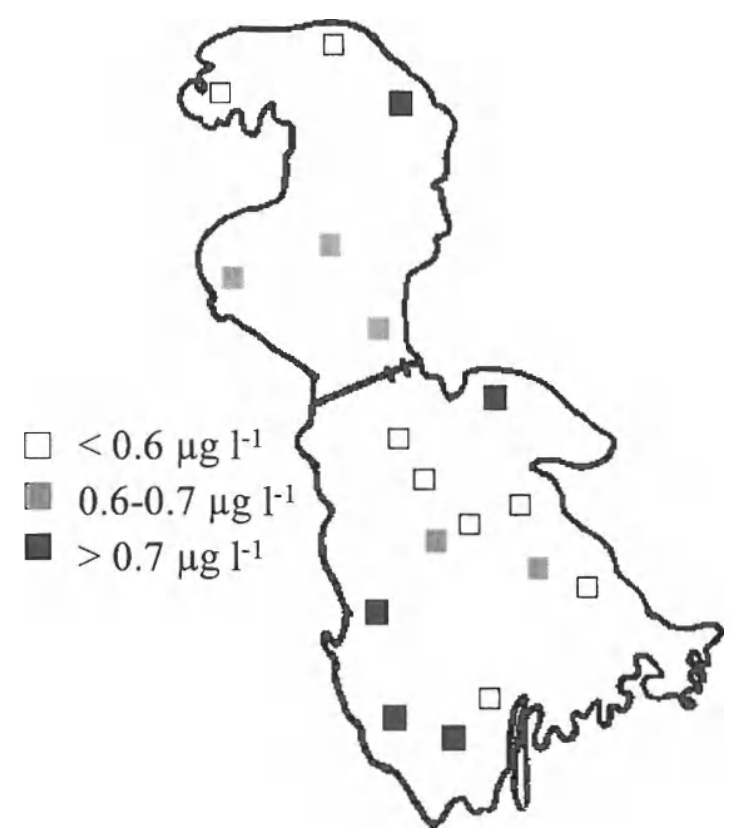

Figure \&. I acal variations in chlorophyll a concentration (values, with standard error bars, are averages over entire sampling period).

tion was interrupted or not enough data were available. According to the available field data, A. urmiana reproduced predominantly oviparously (Fig. 12); in summer a minority of the population (below $30 \%$ ) pro- 


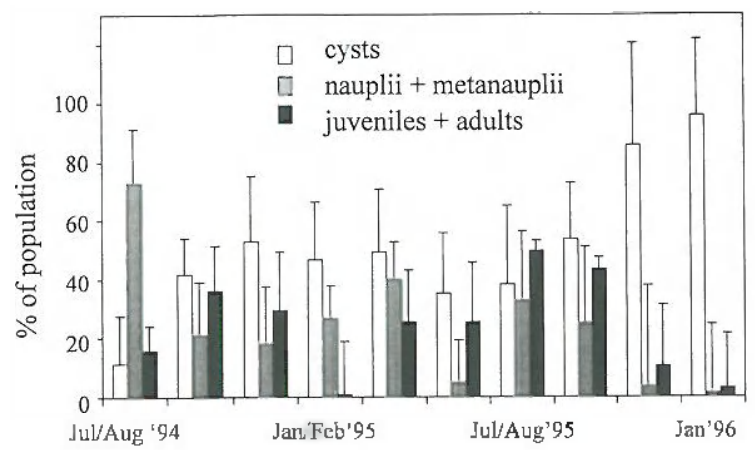

Figure 9. Seasonal fluctuations of Artenia population composition (values, with standard error hars, are averages of all sampling sites).

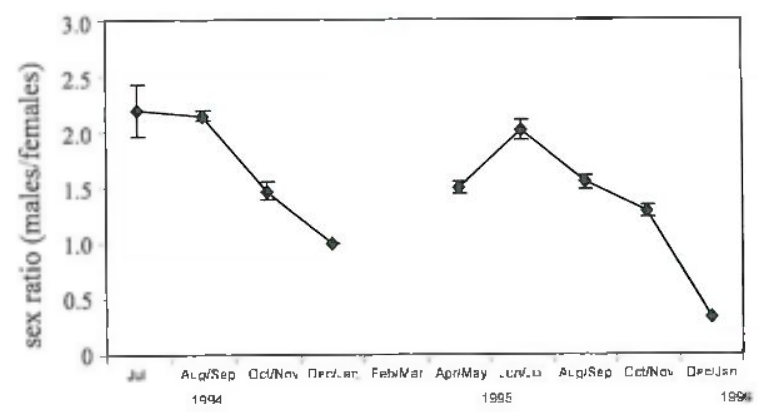

Figure 10. Seasonal fuctuations of sex ratio (values, with standard error bars, are averages of all sampling sites).

duced nauplii. From August onwards, more than $90 \%$ of the reproducing females produced cysts.

The average brood size was very high (Fig. 13): for cyst production, the average clutch size ranged around $70-80$ cysts brood ${ }^{-1}$ in the period August-December, while in other months the number of cysts brood ${ }^{-1}$ never dropped below 30 . For ovoviviparous reproduction, brood size ranged between $\sim 75$ nauplii brood $^{-1}$ in July and 5-10 from September onwards. The max-

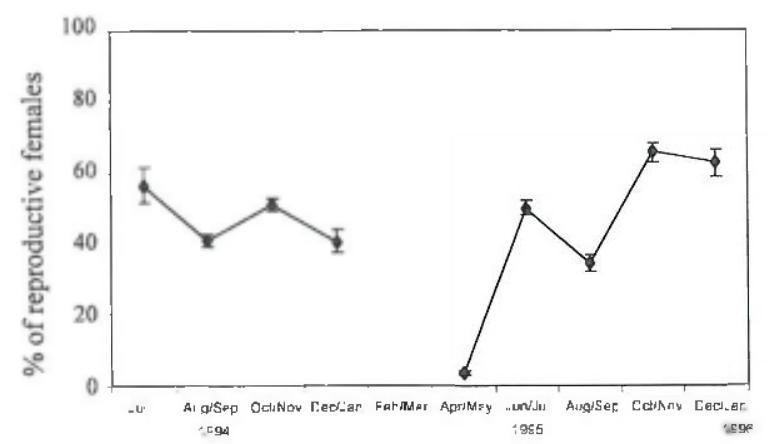

Figure 11. Seasonal fluctuations of percentage of reproductive Arfemia females over tolal females (values, with standard error bars, are averages of all sampling sites).

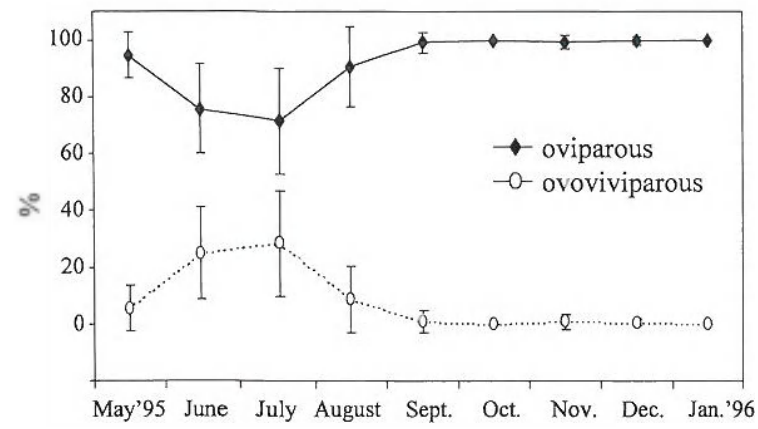

Figure 12. Seasonal flucluations of percentage of Artemia females reproducing oviparously versus ovoviviparously (values, wilh standard error bars, are averages of all sampling sites).

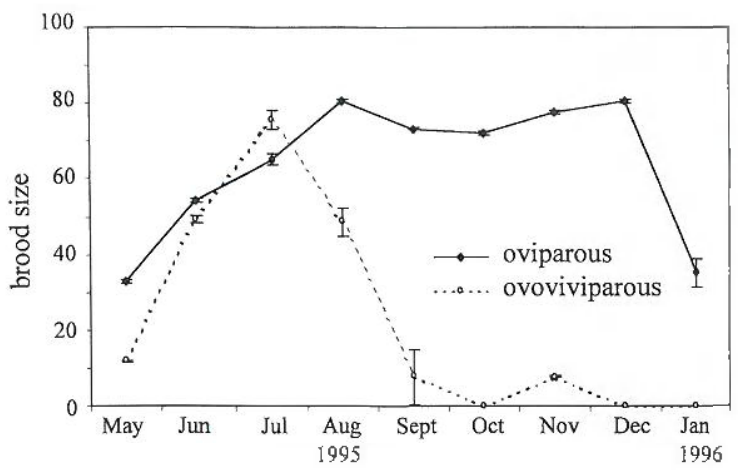

Figure 13, Seasonal fluctuations of brood size (oviparous versus ovoviviparous reproduction) (values, with standard error bars, are averages of all sampling sites).

imal individual brood sizes recorded were 269 cysts and 216 nauplii (both in August).

Artemia biomass reached its maximum in the period August-December (Fig. 14). The maximal values measured in autumn $1995\left(\sim 30 \mathrm{~g}\right.$ wet weight $\left.\mathrm{m}^{-3}\right)$

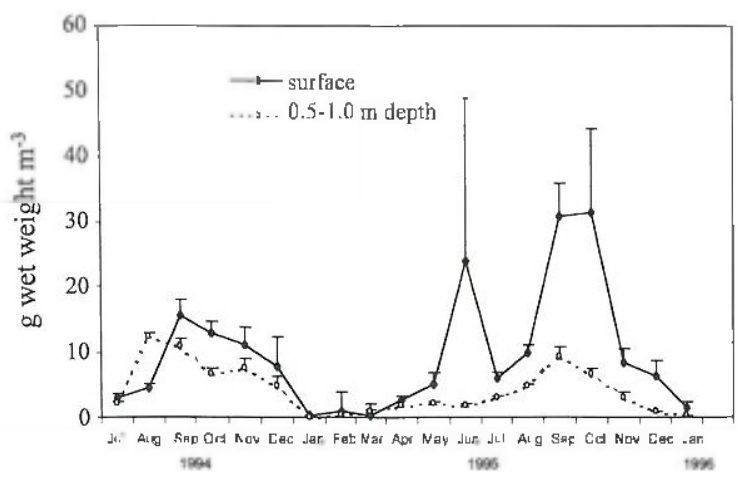

Figure 14. Seasonal fluctuations of A rtemia biomass density (wet weight) al water surface and at $0.5-1.0 \mathrm{~m}$ water depth (values, with standard error bars, are averages for all t- and p-sampling sites, respectively). 


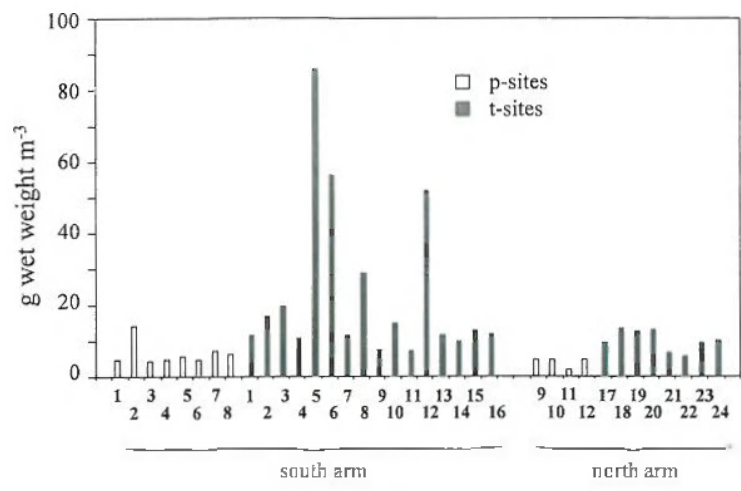

Figure 15. Local variations in Artemia biomass density (wet weight) at water surface (1-samples) and $0.5-1.0 \mathrm{n}$ depth (p-samples) (values are averages over entire sampling period).

greatly exceeded the values for $1994\left(15 \mathrm{~g} \mathrm{~m}^{-3}\right)$ (both 1-site samples). No such difference was recorded for the subsurface (p-site) samples. An important fraction of the Artemia biomass was present below $0.5 \mathrm{~m}$ water depth. The helerogeneity of the Artemia distribution was reflected in the occurrence of extreme values, which affected the monthly average; e.g., the unusually high value of June 1995 was due to the sampling in a streak of accumulated biomass at a few sites.

The average amount of biomass, harvested per sampling run at each site, was situated in the range 10 $20 \mathrm{~g} \mathrm{~m}^{-3}$ (equivalent to a density of one to two adults $\left.1^{-1}\right)$, but at some sites $\left(t_{5}, t_{6}, t_{8}, t_{12}\right)$ higher densities were encountered (Fig. 15). As with temporal abundance these average values were strongly affected by the incidental occurrence of hiomass accumulations. Exceptionally high values were not encountered in the north arm, suggesting a generally lower biomass production for this part of the lake. Values were generally lower for the samples taken below the water surface (p-samples).

\section{Discussion}

\section{Introduction}

Data available in literature ahout Artemia ecology and distribution, as well as studies of population dynamics and biomass estimation are uncommon, and are often restricted to either artificial environments (e.g., Artemia production ponds) or to natural ecosystems of much smaller size than Lake Urmiah. Persoone \& Sorgeloos (1980) and Lenz (1987) review literature data on the productivity of Artemia habitats in natural environments, hoth inland and coastal salt lakes. Lenz
\& Browne (1991) list a number of field studies, performed on natural Artemia populations. Artemia from Mono I ake have been the subject of a life history study by Lenz $(1980,1984)$ and long-term monitoring (Melack \& Jellison, 1998).

Only the Great Salt Lake, Utah, USA, until recently the source of the large majority of raw cyst material on the world market (Lavens \& Sorgeloos, 2000), is of dimensions comparable to Lake Urmiah and has been the subject of numerous ecological and Artemia population studies (Stephens, 1974). In recent times the Great Salt Lake has seen considerable salinity fluctuations with consequent changes in the ecosystem (Wurtsbaugh \& Smith Berry, 1990; Stephens, 1997). Gliwicz et al. (1995) conducted a population study shortly after a 6-year drought period, when salinity in the lake was $140 \mathrm{~g} \mathrm{~J}^{-1}$. The authors state that, in spite of the simplicity of the trophic structure (short food chain) and the limiled biodiversity of this ecosystem, it is difficult to assess the consequences of abiotic fluctuations and shifts in phytoplankton concentration/composition on the Artemia franciscana population. While during periods of excessive rainfall, predators of Artemia might survive in lower salinity zones and have a deleterious effect on the brine shrimp population, annual fluctuations often occur in the brine shrimp population without indication of the causative factor.

As morphometric, genetic and reproductive studies (Abreu-Grobois \& Beardmore, 1991; Pilla. 1992: Pilla \& Beardmore, 1994; Pador, 1995; Triantaphyllidis et al., 1997) have shown the separate status of the species Artemia urmiana, it is possible that observations for A. franciscana cannot be extrapolated as such to Lake Urmiah.

\section{Abiotic conditions}

According to Lenz. (1987), seasonality in the brine shrimp population of large temperate lakes is primarily determined by the temperature cycle. Water temperatures around $0^{C} \mathrm{C}$ can preclude the survival of al] Artemia life stages but cysts, or allow adults and juveniles to survive at low densities (Lenz \& Browne, 1991). Vanhaecke et al. (1984) studied the combined effects of temperature $\left(18-34^{\circ} \mathrm{C}\right)$ and salinity (5-120 $\mathrm{g}^{-1}$ ) on the survival of Artemia of various geographical origin (not including $A$. urmiana), and found that both variables significantly affect survival, the effect of temperature heing more pronounced. No single strain, however, seemed to be stenothermal, 
while most strains shared a common area of preference $\left(20-25^{\circ} \mathrm{C}\right)$, where mortalities were below $10 \%$ after a culture period of 9 days. Substantial strain differences, however, existed with regard to resistance for high temperatures: A. salina and A. parthenogenetica strains did not survive temperatures exceeding $30^{\circ} \mathrm{C}$, while 5-10\% survival was observed for both Great Salt Lake and San Francisco Bay A. franciscana, cultured at $34^{\circ} \mathrm{C}$. Lethal temperatures of $30-34^{\circ} \mathrm{C}$ were however never attained at the water surface of Lake Urmiah.

Von Hentig (1971) assumes maximal hatching in the range $15-30^{\circ} \mathrm{C}$, while Sorgeloos \& Persoone (1975) narrow it down to $20-28^{\circ} \mathrm{C}$. Nevertheless hatching can occur at lower temperatures (as low as $5-10^{\circ} \mathrm{C}$, be it at much slower hatching rates) observed in Lake Urmiah from late February or early March onwards. Maximal grow th and biomass production takes place in the range $20-27^{\circ} \mathrm{C}$ (Vanhaecke \& Sorgeloos, 1989). Once again, the impact of temperature on growth varies from one strain to another. However, for most strains growth is limited below $15^{\circ} \mathrm{C}$. This laboratory finding is also confirmed by field data (Lenz \& Browne, 1991). If these data are extrapolated to $A$. urmiana, the season for optimal biomass production in Lake Urmiah is confined to the period April-October.

Large local salinity differences were not recorded in this sampling campaign. Gliwicz et al. (1995) found that salinity was homogeneous over the entire south arm of Great Salt Lake, and over a total depth of $6 \mathrm{~m}$, indicating that thorough horizontal and vertical mixing of the water column takes place.

As in Lake Urmiah, transparency in Great Salt Lake (Gliwicz et al., 1995) appeared to be highly variable $(0.4-7.0 \mathrm{~m})$ depending on time and sampling site. Seasonal fuctuations in primary productivity and the stirring of bottom sediments by wind and waves affected the transparency of the water column.

Mono Lake (Lenz, 1984) shows seasonal and annual transparency fluctuations, with minimal values in the period October-May and peaks in July-August, reflecting the heavy grazing pressure of the brine shrimp population.

\section{Algal biomass}

Chlorophyll values in Lake Urmiah, generally situated in the range $0.5-0.8 \mu \mathrm{g} \mathrm{I}^{-1}$, are low compared to the values reported by Gliwicz et al. (1995) for Great Salt Lake $\left(<0.5 \mu \mathrm{g} \mathrm{I}^{-1}\right.$ in June to $13 \mu \mathrm{g} \mathrm{I}^{-1}$ in January). Even values observed in the more productive estuarine zones of Lake Urmiah were well below the chlorophyll a levels observed in similar areas in Great Salt Lake (60 $\left.\mu \mathrm{g} \mathrm{I}^{-1}\right)$. In summer under high grazing pressure, the algal species composition in Great Salt Lake was more diversified (with an important fraction of diatoms like Amphora, Navicula and Nitzschia) than in winter, when the phytoplankton mainly consisted of a Dunaliella monoculture.

The Lake Urmiah study did not assess bacterioplankton and decomposing matter (detritus), potentially important food sources for the Artemia population. Detritus can be up-welled by water currents and storms and bacterioplankton can be abundant. In the zones of river water inflow and in fooded areas decaying matter may contribute significantly to the nutrient balance of the lake. Gliwicz et al. (1995) state that food limitation induces a stage-structured intraspecific competition on growth rate: in an environment with limited primary production the adults compete successfully for food with the carlier stages, resulting in reduced naupliar growth. Culture tests of Great Salt Lake-Artemia in vitro and analysis of stomach content in the field show that nauplii and young juveniles mainly thrive on phytoplankton and other suspended material. Adults and subadults use this food source only in case its concentration is high, and otherwise consume sedimented detritus and periphyton (in summer the periphyton on exuviae is an important food source).

\section{Artemia population}

Comparison of the seasonal fluctuations in population composition (Fig. 9), chlorophyll concentration (Fig. 7) and transparency (Fig. 5), suggests the following population dynamics at Lake Urmiah. A fraction of nauplii and metanauplii may survive the winter months, and start developing from March/April onwards. However, it is difficult to assess the contribution of this overwintering population to the spring generation of adults. Hatching of cysts may occur as early as February. The grazing pressure of this expanding brine shrimp population prevents the phytoplankton from reaching actual blooming concentrations, as observed in other saline habitats in late spring. Consequently, as the number of juveniles and adults increases, the algal concentration steadily declines and reaches absolute minimum levels in late spring, early summer (May/June), after which transparency gradually decreases (late summer, early autumn), even 
though the relative proportion of juveniles and adults is reaching a maximum.

Gliwicz et al. (1995) summarize the population dynamics in Great Salt Lake as follows: in April/May a first generation hatches from cysts and colonizes the environment rapidly. This generation reproduces ovoviviparously at a high rate, illustrated by large broods of nauplii during late May. These animals produce a second generation of more slowly developing individuals, which do not reach maturity by autumn. Only a small fraction of this second generation seems to survive and reach maturation, producing one or two smaller bronds, which do not contribute significantly to the population density. In Mono I ake (Lenz, 1980, 1984; Jellison \& Melack, 1998) the number of Artemia is low during winter and the brine shrimp females remain in a non-reproductive state. In spring the Artemia develop slowly from cyst to adult in 10-12 weeks, mainly because of the low prevailing water temperatures, and reach maturity at the end of May, reproducing ovoviviparously. Second generation adults appear in mid-July/August. The first and second generation of females in July produce overwintering cysts. The population reaches a peak in late summer, decreasing afterwards to low numbers in November. However, considerable fluctuations are observed from year to year. For Lake Urmiah, the field data do not allow definitive conclusions with regard to the number of generations produced per season; however, the reproductive data (see further) indicate a predominance of oviparity, suggesting that ovoviviparous colonization of the medium does not take place at a rate comparable to the Great Salt Lake.

The high incidence of males in Lake Urmiah corresponds to the observations in other saline lakes, e.g." Mono Lake (Lenz, 1984) and particularly Great Salt Lake, where similar fluctuations occur, with a sex ratio of $4: 1$ in June, decreasing to $1: 1$ in November/December (Gliwicz et al., 1995). These fluctuations may be related to the different physiological tolerance of adult males and females to varying conditions of temperature, salinity and/or oxygen, not specific for A. urmiana, but also for other Artemia species.

The data on sex ratio do not permit any decisive conclusions regarding the possible coexistence of a parthenogenetic and a bisexual brine shrimp species in Lake Urmiah. Günther (1890) described brine shrimp from Lake Urmiah as a unique bisexual species, Artemia urmiana. This characteristic was confirmed when Clark \& Bowen (1976) demonstrated the repro- ductive isolation of the species from other bisexual strains. Nevertheless, Barigozzi et al. (1987) reported a population exclusively composed of parthenogenetic individuals after culturing two cyst samples in the laboratory, and proposed to cancel the species designation A. urmiana. Azari Takami (1989) reported the coexistence of hisexual and parthenogenetic populations in the lake. He ohserved that the parthenogenetic strain was dominant in spring and summer but not common in aulumn and winter. The phenomenon of coexistence with varying frequencies throughout the year has already heen reported in other Artemia biotopes (Amat, 1983; Perez, 1987). Barigozzi (1989) proposed to reconsider A. urmiana as a species, and Ahmadi et al. (1990) reinforced the idea that the lake sustains a mixed population. Pador (1995), who cultured animals using cysts collected from different sampling stations, found no evidence of a parthenogenetic population. Although the occurrence of a parthenogenetic strain thus remains a possibility, the sex ratio suggests that the Artemia population in Lake Urmiah is at least predominantly bisexual.

The average clutch size (Fig. 13) largely surpasses the average value of 48 eggs female ${ }^{-1}$ reported in laboratory experiments under optimal feeding conditions and a salinity of $140 \mathrm{~g}^{-1}$ (Pador. 1995). Equally low values were found in nature for Great Salı Lake Artemia, where the average brood size in summer and fall fluctuated around 15-30 eggs female ${ }^{-1}$. In estuarine areas, however, a maximum of 155 eggs female ${ }^{-1}$ was recorded for females larger than $10 \mathrm{~mm}$, and 50 for smaller individuals $(7-8 \mathrm{~mm})$. In laboratory experiments with optimal feeding conditions on the contrary, a maximum of 190 eggs female ${ }^{-1}$ was recorded (Gliwicz et al., 1995), illustrating the effect of food availability on brood size. Lower food availability induced oviparous reproduction, decreased brood size and increased the interval in between broods.

The seasonal decline in percentage of ovoviviparous females in Lake Urmiah (Fig. 12), as well as the decrease in nauplii brood ${ }^{-1}$ (Fig. 13) from July onwards, coincides with the increased transparency (Fig. 5) and thus depletion of phytoplankton. Remarkably, there is no decrease in cysts brood ${ }^{-1}$ before the winter season; Belovsky (1996) notes that cyst production in Great Salt Lake brine shrimp is highest at intermediate food concentrations. Throughout summer and aulumn a maximum of reproductive effort is thus invested in cyst production, with nearly all reproductive females producing high numbers of cysts. 
The difference in parameters, utilized to express the Artemia standing crop, and the divergent values found in literature, confirm that the assessment of the quantity of brine shrimp in a saltwater body is difficult. The distribution of Artemia, which are posilively phototactic and subject to water currents by the action of wind, is highly heterogeneous and thus densities may vary widely (Persoone \& Sorgeloos, 1980). For instance, Lenz (1980) reports densities ranging from 1 to 400 ind. $\mathrm{l}^{-1}$ in Mono Lake, while Mason (1967) reports only a few adults $]^{-1}$ in the top water layer in Mono Lake. In the Lake Urmiah sampling campaign, the hour of sampling was randomized and only occasionally were samples taken in deeper water layers; consequently no information on diurnal migration of the brine shrimp population could be obtained.

If the wet weight of an Artemia adult is estimated at $\sim 10 \mathrm{mg}$ individual ${ }^{-1}$ (Reeve, 1963), a density of $30 \mathrm{~g} \mathrm{~m}^{-3}$ corresponds with a density of 3 adults $1^{-1}$, a relatively low figure compared to the values presented for Great Salt Lake: 4 adults $1^{-1}$ in July (Wirick, 1972); 20 and 10 ind. $1^{-1}$ for June and July, respectively (Stephens \& Gillespie, 1972); 10-20 ind. $\mathrm{I}^{-\mathrm{I}}$ in late spring (Wurtsbaugh \& Smith Berry, 1990). Artemia production in Great Salt Lake is estimated by Gillespie \& Stephens (1977) at 100-200 g biomass (dry weight) $\mathrm{m}^{-2}$ year $^{-1}$.

Although caution is needed when comparing Artemia density values from different lakes, recorded over different seasons with various sampling methods, the Artemia production of Lake Urmiah seems relatively low. These low values correspond well with the low algal biomass values; Belovsky (1996) confirms that in Great Salt Lake the highest Artemia densities coincide with the highest food concentration, illustrating the impact of food availability.

Long-term hydrological records prove that the water level of Lake Urmiah is subject to substantial fluctuations (Fayazi, pers. commun.), caused by climatological factors. In view of the unusual weather conditions that prevailed in the period 1994-1996 (mild winter temperatures, excessive rainfall) the field data cannot be extrapolated as such to production years when more normal weather conditions are to be expected. Since 1996, salinity has steadily increased again, due to reduced precipitation, and presently (fall 1999) it is as high as $240 \mathrm{~g} \mathrm{l}^{-1}$ (Fayazi, pers. commun.). Continued sampling is needed to acquire more insight into the population dynamics of Artemia urmiana.

\section{References}

Abreu-Grobois, F. A. \& J. A. Beardmore, 1991. Genetic characterization and intrageneric relationships of Artemia monica Verril] and $A$. utrmiana Günlher. Hydrobiologia 212: 151-168.

Ahmadi, M. R. M.. H. I.eibovitz \& K. Simpson, 1990, Characterisation of Uromiah Lake Artemia (Artemia uromiana) by electrofocusing of isozyme patterns. Comp. Biochem. Physiol. 95: 115-118

Amat, D. F., 1983. Zygogenetic and parthenogenetic Artemia in Cadiz sea-side salterns. Mar. Ecol. Prog. Ser. 13: 291-293.

Azari Takami, G., 1987. The use of Artemia from Ormia Lake (Iran) as food for sturgeon. In Sorgeloos. P., D. A. Bengtson, W. Decleir \& E. Jaspers (eds), Artemia Research and its Applications, 3. Ecology, Culturing, Use in Aquaculture. Universa Press, Wetteren, Belgium: 467-468.

Azari Takami, G., 1989. Two strains of Artemia in Urmia Lake (Iran). Artemia New slett. 13: 5.

Azari Takami, G. 1993. Urmiah lake as a vuluable source of Artemia for feeding sturgeon fry. J. Vet. Fac. Univ. Tehran 47: $2-14$

Barigozzi, C., 1989. The problem of Artemia urmiana. Artemia Newslett. 14: 14.

Barigozzi, C., V. Varotto, L. Baratelli \& R. Giarizo, 1987. The Artemia of Urmia Lake (Iran): mode of reproduction and chromosome numbers. Atti. Acc. Lincel. Rend. Fis. 8 (LXXXI): $87-90$.

Belovsky, G. E., 1996. Brine shrimp population dynamics and sustainable harvesting in the Great Salt Lake Utah. Department of Fisheries and Wildlife and Ecology center Utah State University, Logan, Utah. 1996 Progress Report to the Utah Division of WiIdlife Resources.

Clark, L. S. \& S. T. Bowen, 1976. The genetics of Artemia salina. VII. Reproductive isolation. J. Hered. 67: 385-388.

Ghaheri, M., M. H. Baghal-Vayjooee \& J. Naziri, 1999. Lake Urmia, Iran: a summary review: Int. J. Salt Lake Res. 8: 19-22.

Gillespie, D. M. \& D. W. Stephens, 1977. Some aspects of plankton dynamics in the Great Sait Lake, Utah. In Greer, D. C. (ed.), Desertic Terminal Lakes. Proc. Int. Conf. Desertic Termina] Lakes. Utah State University, Logan, UT. USA: 401-409.

Gliwicz, Z. M., W.A.Wurtsbaugh \& A. Ward, 1995. Brine shrimp ecology in the Great Salt Lake, Utah. June 1994-Mlay 1995 Performance Report to the Utah Division of Wildlife Resources, Salt Lake City, UT: 83 pp.

Günther, R. T., 1890. Contributions to the natural history of Lake Urmi, N. W. Persia and its neighbourhood. J. Jinn. Soc. London 27: $394-398$.

Lavens, P. \& P. Sorgeloos, 2000. The history. present status and prospects of the availability of Artemia cysts for aquaculeure. Aquacullure 181: 397-403.

Lenz, P. H., 1980. Ecology of an alkali-adapted variety of Artemia from Mono Lake, California, USA. In Persoone, G., P. Sorgeloos, O. Roels \& E. Jaspers (eds), The Brine Shrimp Artemia, 3. Ecology, Culturing, Use in Aquaculture. Universa Press, Wetteren. Belgium: 79-96.

Lenz, P. H-, 1984. Life-history analysis of an Artemia population in a changing environment. J. Plankton Res. 6. 967-983.

Lenz, P. H., 1987. Ecological studies on Artemia: a review. In Sorgeloos, P., D. A. Bengtson, W. Decleir \& E. Jaspers (eds) Artemia Research and its Applications, 3. Ecology, Culturing, Use in Aquaculture. Universa Press, Wetteren, Belgium: 5-18.

Lenz, P. H. \& R. A. Browne, 1991. Ecology of Artemia. In Browne, R. A., P. Sorgeloos \& C. N. A. Trotman (eds), Artemia Biology. CRC Press Inc. Boca Raton. FL 33431, USA: 237-253. 
Löffler, H., 1961. Bejtrage zur Kenntris der Iranischen Binnengewasser. II. Regional-Limnologische Studie mit hesonderer Berücksichtigung der Cnistaceeenfauna. Int. Rev. ges. Hydrobiol. Hy drogr. 46: 309-406.

Mason, D. T., 1967. Limnology of Mono Lake, California, U. Calif. Public. Zoology 83: 1-110.

Melack, J. M. \& R. Jellison, 1998. Limnological conditions in Mono Lake; contrasting monomixis and meromixis in the 1990s. Hydrobiologia 384: 21-39.

Pador, E., 1995. Characterisation of the Artemia urmiana Gunther 1900 from Lake Urmia, Iran. M.Sc. Thesis, Yrije Universiteit Brussel and Laboratory of Aquacuiture - Anemia Reference Center, University of Ghent, Belgium, $61 \mathrm{pp}$.

Perez, R., 1987. Cyst production of Artemia in salt ponds in southeastem Spain. In Sorgeloos, P. D. A. Bengston. W. Decleir \& E. Jaspers (eds). Artemia Research and its Applications, 3. Unjversa Press, Wetteren, Belgium: 215.

Persoone, G. \& P. Sorgeloos, 1980. General aspects of the ecology and biogeography of Artemia. In Persoone, G., P. Sorgeloos, O. Roels \& E. Jaspers (eds), The Brine Shrimp Artemia, 3. Ecology, Culturing, Use in Aquaculture. Universa Press, Wetteren, Belgium, 3-24.

Pilla, E. J., 1992. Genetic differentiation and speciation in old world Artemia. Ph.D. thesis. Department of Genefics. University College of Suansea. UK, $356 \mathrm{pp}$.

Pilla, E. J. \& J. A. Beardmore, 1994. Genetic and morphometric differentiation in Old World bisexual species of the brine shrimp (Ariemia). Heredity 73: 47-56.

Recre, M. R., 1963. Growth efficiency in Artemia under laboratory conditions. Biol. Bull. 125: 133-145

Sorgeloos, P. \& G. Personne, 1975. Technological insprovements for the cultivation of invertebrates as food for fishes and crustaceans. II. Hatching and culture of the brine shrimp Artemia salina $\mathbf{L}$ Aquaculture 6: 303-317.
Stephens, D. W . 1974. A summary of biological investigations concerning the Great Salt Lake, Utah (1861-1973). Great Basin Naturalist $34: 22$ i-229.

Stephens, D. W., 1997. SaTinity-induced changes in the aquatic ecosystem of Great Salt Lake, Utah. In Pitman, I. \& A. Carroll (eds), Modern and Ancient Lake Systems: New Probiems and Perspectives. Utah Geolngical Association Guidebook 26. 3-7.

Stephens, D. W. \& D. M. Gillespie, 1972. Community structure and ecosystem analysis of the Great Salt Lake. In Riley. J. P. (ed.), The Great Lake and IJah's Water Resources. Utah Water Res. Lab., Utah State University, USA: 66-72.

Strickland, J. D. \& T. R. Parsons, 1972. A Practical Handbook of Seawater Analysis, 2nd edn. Bull. Fish, Res. Bd Carl. 167, 310 pp.

Triantaphyllidis, G. V.. G. R. J. Criel, T. J. Abatzopoulos \& P. Sorgeloos, 1997. International Study on Artemia. LIr\}, Morphological study of Artemin with emphasis to Old World strains. I. Bisexual populations. Hydrobiologia, 357: 139-153.

Vanhaecke, P. \& P. Sorgeloos, 1989. International Stuly on Artemia. XLYII. The effect of temperature on cyst hatching, larval surival and biomass production for different geographical strains of brine shrimp Artemia spp. Ann. Soc. r. zool. Belg. 119(1): $7-23$.

Vanhaecke, P. S. F. Siddal \& P. Sorgeloos. 1984. Internaticnal Study on Artemia. XXXIl. Combined effects of temperature and salinity un the survival of Artemict of various geographical origin. I. exp. mar. Biol. Ecol. 80: 259-275.

Von Hentig, R.. 1971. Einfluss von Salzgehalt und Temperatur auf Entwicklung, Wachstum, Fortpflanzung und Energiebilanz von Artemia salina. Mar. Biol. 9: 145-182.

X'irick, C. D., 1972.Dunaliella-Artemia plankton community of the Great Salt Lake, Utah. Thesis, University of Utah. USA, 44 pp.

Wurtsbaugh, W. A, \& T. Smith Berry, 1990. Cascading effects of decreased salinity on the planklon. chemistry and physics of the Great Salt Lake (Utah), Can. J. Fish. aquat. Sci., 47: 100-109. 
